Litteratur

1. Losvik OK. Ytringsfrihed burde funnet Sted. Tidsskr Nor Legeforen 2014; 134: 818

\section{Re: Ytringsfrihed burde funnet Sted}

Ole Kristian Losvik har skrevet en fin artikkel (1). Jeg vil oppfordre yngre kolleger til å vekte lojalitetsplikten mot pasientene høyere enn lojalitetsplikt mot arbeidsgiver - en sikker vinneroppskrift $i$ det lange løp, etter min erfaring. Det møter gjerne motstand i systemet, men slike leger vil både pasienter og politikere ha når de har tenkt seg om. Lojalitet mot pasienten er første bud!

\section{Kjetil Retterstøl}

kjetil.retterstol@medisin.uio.no

Kjetil Retterstøl (f. 1962) er overlege ved Oslo universitetssykehus. Ingen oppgitte interessekonflikter.

\section{Litteratur}

1. Losvik OK. Ytringsfrihed burde funnet Sted. Tidsskr Nor Legeforen 2014; 134: 818 .

\section{Re: Polypillen - et alternativt konsept i kardiovaskulær profylakse}

Kronikken til Sandli, Slørdahl og Spigset (1) om polypillen som alternativt konsept i kardiovaskulær profylakse er interessant, men nytteeffekt av polypille kan ikke påvises i særlig grad av de studier som er utført. Et helsemessig uheldig forhold er at å ta i bruk en polypille vil bidra til ytterligere medikalisering av en stor gruppe friske mennesker.

Ideen ble lansert av de britiske epidemiologene Wald og Law i 2003 (2). Som et alternativ til polypillen lanserte Franco og medarbeidere året etter «The polymeal: a more natural, safer and probably tastier (than the Polypill) strategy to reduce cardiovascular disease by more than $75 \%$ \% (3). Med samme metode som ble brukt av Wald og Law, søkte forfatterne etter studier og fant god evidens for at følgende kost- og næringsmidler bidrar til å redusere risiko for hjerte-kar sykdom: vin, fisk, mørk sjokolade, frukt og grønnsaker, mandler og hvitløk. De kalkulerte at daglig inntak av kombinasjonen av alle ingredienser i et «Polymeal» vil redusere risikoen for kardiovaskulær sykdom med $76 \%$ !

I diskusjonen fastslår de at polymåltidet er et effektiv, naturlig, sannsynligvis sikrere og mer smakfullt alternativ enn polypillen. Av bivirkninger nevnes kroppslukt av hvitløk, men forfatterne mener at når hvitløk blir implementert $\mathrm{i}$ hele befolkningen blir duften så vanlig at ingen bryr seg lenger! Og på grunn av hvitløken advarer forfatterne mot polymåltidet forut for romantiske møter, med mindre ikke også den andre har inntatt et polymåltid. Problemet med kvikksølv i fisk blir også nevnt, men forfatterne angir at dette er mest $i$ hai og sverdfisk, som jo ikke er vanligste fiskeslag på norske middagsbord. I polymåltidet inngår $150 \mathrm{ml}$ vin, og forfatterne advarer mot høyere konsum. Forfatterne påpeker også forventet økt risikoreduksjon hvis man etter inntak av polymåltidet mosjonerer minst en halv time.

Det konkluderes med at polymåltidet er lovende som et effektiv, ikke-farmakologisk, sikkert og smakfullt alternativ for reduksjon av risiko for hjerte- og karsykdom og vil øke livsutsiktene i den generelle befolkningen.

\section{Torgeir Fjermestad}

torgeirf@online.no

Torgeir Fjermestad (f. 1954) er fastlege ved Ranheim legesenter. Ingen oppgitte interessekonflikter.
Litteratur

1. Sandli OK, Spigset O, Slørdal L. Polypillen-et alternativt konsept i kardiovaskulær profylakse. Tidsskr Nor Legeforen 2014: 134: 632-4.

2. Wald NJ, Law MR. A strategy to reduce cardiovascular disease by more than $80 \%$. BMJ 2003: 326: 1419-23.

3. Franco $\mathrm{OH}$, Bonneux $L$, de Laet $\mathrm{C}$ et al. The Polymeal: a more natural, safer, and probably tastier (than the Polypill) strategy to reduce cardiovascular disease by more than $75 \%$. BMJ 2004: 329: 1447-50.

\section{Re: Spesiell bok med misvisende tittel}

La det være sagt med en gang: Det er alltid artig å lese hva andres hjerner oppfatter av hva en selv har produsert og satt på papiret. Så også denne anmeldelsen av boken «Ja takk, begge deler!», som jeg er medforfatter på (1). Som forfatter og forlegger har jeg hatt stor glede av de bitreste og kritiske tilbakemeldinger, like mye som overstrømmende ros.

Som pedagog, foredragsholder, forfatter og forlegger bruker jeg tid på å studere kommunikasjon og analysere hvordan ulike mennesker reagerer på samme budskap. Jeg har da erfart at reaksjonene beror på det vi i neurolingvistikken kaller trossystemer, som igjen er en ordning av prosedyrer vi bruker for å overleve, som omgjøres til absolutte sannheter. Det er dette jeg har forsøkt å analysere i mine bidrag i boken; hvordan det vi kaller skolemedisin ikke er en samling av vitenskapsfakta, men en trosbasert ordning av fakta som tidvis er til gang og tidvis til skade for syke, og for vår egen selverkjennelse. Naturmedisinen bør ikke unndras den samme analyse, men det var ikke hva man ba meg skrive om denne gangen. Opprinnelig skulle mitt innlegg være om forskning på resonanssystemer og informatikk i neuro-biocybernetikk som forklaringsmodell for akupunkturterapi. Så ble det i stedet en analyse av hjernens arbeidsmetoder for å skape trossystemer.

Jeg synes det er meget morsomt at anmelderen har festet seg ved metaforen med skolemedisin som et synkende skip. Nei da, det mener vi ikke. Faget er i høyeste grad et oppgående krigsskip. Metaforen derimot, er ikke hva man skrev, den er basert på lystig vitsetegning for å sprite opp boken, som gjør litt narr av debatten mellom skoleleger og naturleger med spark til begge sider. At denne vitsetegningen har festet seg hos anmelder bekrefter hva vi vet innen kommunikasjon: et bilde taler mer enn tusen ord. Kanskje man neste gang burde få frem budskapet ved en tegneserie?

Og blir det noen gang «ja takk, begge deler» for pasientene, slik bokens redaktør har valgt som tittel? Vi får se. Internett er nå det sted der legevitenskapen settes under kritikk, og nye erkjennelser spres i det neuro-elektroniske nettverket. Vi inviterer derfor kolleger til å skrive en bok: «Legen I Internettets Tidsalder: om legerolles forfall og vekst under presset av det digitale samfunn.» Interesserte kolleger kan ta kontakt.

\section{Bjørn Johan Øverbye}

bjorn@dr-overbye.no

Bjørn Johan Øverbye (f. 1947) er forfatter, forlegger og lege. Ingen oppgitte interessekonflikter.

Litteratur

1. Norheim AJ. Spesiell bok med misvisende tittel. Tidsskr Nor Legeforen 2013; 133: 1220

\section{Re: For mange pasienter er farlig}

Utviklingen med stadig høyere pasientbelegg som Gjessing beskriver i sin leder i Tidsskriftet nr. 14/2014 (1), gir ringvirkninger over i kommunal helsetjeneste. Når pasienter skrives ut i betydelig dårligere tilstand enn før, stilles økte krav til fastleger, hjemmesykepleie og sykehjem. Samtidig øker antall reinnleggelser av pasienter som skrives raskt ut fra sykehus. Fastlegekorpset er ikke styrket i takt 